\title{
Additional Notes to the Hainan Birds Masauji Hachisuka
}

Since the publication of my book, Contribution on the Birds of Hainan, in 1939, I have found it necessary to alter some of the nomenclature and to add some species which were overlooked in my previous work.

A Tentative list of Chinese Birds, $1926-27$ by G. D. Wilder, N. Gist Gee and Lacy Moffett includes Hainan but because of misprints and the uncertain sources of its records some of the accounts are not definitely authenticated.

Birds of Kwangtung, Kwangsi and Fukien in Sun Yatsen University in Canton, Hong Kong Naturolist, viii, no. 1, pp. 17-28, April, 1937 by Y. S. Fok includes Hainan, and lists 150 species therefrom. On p. 25, Gennaeus whiteheadi, the well known Hainan silver pheasant is reported from Yaoshan, the first time it has occurred outside Hainan.

Numbers given to the following birds refer to those in my book. Change of nomenclature:

$9 \quad$ Sphenocercus sieboldi murielae Delacour becomes S. s. oblitus Hartert.

36 Squatarola squatarola ausiralis Reichen bach becomes S. squatarola $(\mathbf{L}$.)

64 Larus canus major Middendorff becomes L. c. kamtschatschensis (Bonaparte).

109 spizastus nipalensis fokiensis W. L. Sclater becomes S. n. white$h c c d i$ Swann and Wetmore.

126 Caprimulgus macrurus bimaculatus Peale becomes C. m. hainanus Mayr, Ibis, vol. 11, p. 310, 1938. Cheteriang, Hainan. Mayr's name is given to the resident bird and it is still unknown whether or not migrants visit Hainan.

154. Cyanops fä̆er (Swinhoe) becomes C.f. faber (Sw.). Two speci- 
mens of $C . f$. sini Stresemann from Yaoshan in my collection are clearly separable from the Hainan skins. The Hainan barbet is of the nominate race.

156 Drobates major akagera Hachisuka becomes D. m. hainanus (Hartert and Hesse), Orn. Monatsb., p. 192, 1911.

164 Pitta nipalenšsis douglasi O.-Grant becomes $P$. soror douglasi O.Grant. Nipalensis and soror are considered to be distinct species and not races.

284 Pica pica pica (L.) becomes P. p. sericea Gould.

286 Corvus macrorhynchus hainanus Stresemann becomes C. levaillanti hainanus Str.

Additional species from Chinese Birds; Wilder, Gee and Moffett list the following species as occurring in Hainan but the records are unsubstantiated.

27a Esacus recurvirostris (Cuvier). The greater stone-plover was supposed to have taken in December (no year given). 'Peters, Checklist Bds. World, II, p. 297, 1934 also list this species as occurring there. I am unable to trace the original source of these records.

$76 \mathrm{a}$ Nipponia nippon (Temminck). Japanese Crested Ibis.

Family 'Threskiomithidae includes the following two species:

76b Threskiornis melanocephala (Latham). White Ibis.

$76 \mathrm{c}$ Platalea minor Temminck and Schlegel. Black-faced Spoonbill. 78 a Egretta eulophotes (Swinhoe). Chinese Egret.

111a Ichthyophaga nana plumbeus Jerdon, Himalayan Fishing Eagle. Polioaetus humilis major by the three âthors. This eagle is not recorded anywhere east of Tenasserim.

141a Chaetura caudacuta cochinchinensis Oustalet. White-throated or Giant Spine-tailed Swift. They claim this swift breeds on an islet off the south coast.

223a Abrornis albogularis fulvifacies Swinhoe. Fulvous-faced Flycatcher Warbler. Recorded between May and December.

285a Corvus corone orientalis Eversmann. Eastern Carrion Crow. Re- 
corded from Hainan Strait.

Additional species from Birds of Kwangtung etc.: Fok's list was partly compiled and partly based on specimens brought back by an expedition of Sun Ystsen University, Canton to Hainan prior to the Japanese incident in 1937, and it is believed that a well known ornithologist, Mr. Yeu, was in the party.

84a Ixobrychus eurythmus (Swinhoe). Schrench's Little Bittern.

110a Haliaeetus leucogaster (Gmelin). White-breasted Sea Eagle.

La Touche recorded this sea eagle from the coast of Fukien and Kwangtung and Delacour and Jabouille from many localities in Indo-China including Mekong River and large lakes in Cambodia, therefore knowing the general distribution in South China and IndoChina, Fok's record may be authentic. Unfortunately, however I did not find this Hainan collection in Canton during my visit in 1940 .

205 Turdus hortulonum Sclater. Grey-backed Trush.

Fok's record furnishes the second occurrence from Hainan.

273a Stumia stumina (Pallas). Daurian Starling.

287 Corvus frugilegus pastinator Gould. Eastern Rook.

Additions and remarks from other sources:

45a Pseudotantalus guttifer (Nordmann). Nordmann's Greenshank.

Tetsu, Herr Schmacker's collector obtained a pair of these sandpipers February 3, 1891 (?) at Hoihow. It is the only Chinese record.

142a Hemiprocne longipennis concnata (Tickell). Indian Crested Swift.

Père David, during his first voyage to China, noticed this swift flying over his boat in the Formosan channel. None of the British ornithologists who stayed for many years in China ever fame across with it. The authors of chinese Birds stated it is "recorded from South China coast". T.H. Cheng, in A Preliminary Check-list of Birds heretofore recorded from Kwangtung and nearby islands including Hainan. Lingnan Sci. Journ., vol. 19, no. 9, p. 172, May 3, 1940, included the crested swift as occurring from Hainan. I believe 
that Cheng's work is a compilation and the data were miscopied from Chinese Birds.

This swift is an inhabitant of thick woods and could hardly expect to be met with on an open sea. . Pere David apparently must have mistaken a swallow, which in size, shape and manner of flight. is very similar to Hemiprocne. At the time of the observation, David was not very familiar with birds outside of France.

115 Falco tinunclus subsp.? Kestrel.

The dark and pale types of kestrels are found in Hainan. According to the study from rather insufficient material one is identified as the typical race and the other interstinctus:

228 Phylloscopus goodsoni Hartert. Goodson's Warbler.

According to Hartert, Bull. B. O.C. xxxvii, p. 43, 1917, this mysterious warbler is paler than tickelli.

\section{抄錄}

私は 1939 年口本鳥學會より「游南島鳥類目錄」を出版した。この原稿は以

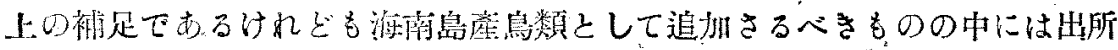

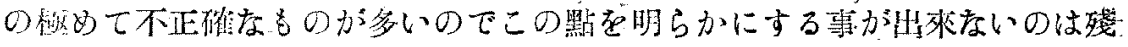

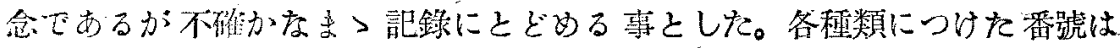

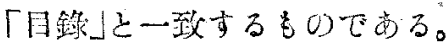

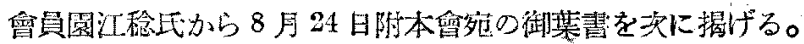

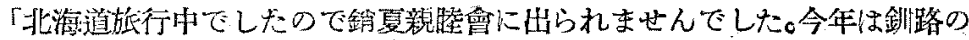

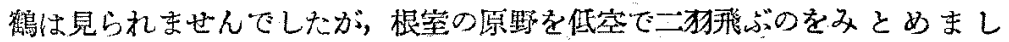
た。標茶留(釧絧線)の前の古川でコバンの萫殖を鹳察しました。街としては，

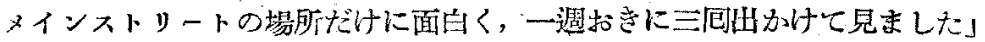

叉9月24 日附九大農學部長江崎悌三氏よりの御葉書には「數日前福剛附近 でッバメチドりを捕へました」とむつた。珍らしいことである。 